\title{
Dilemma Situations in Teaching Practice: What Do Student Teachers Reflect?
}

\author{
Öğretmenlik Uygulamalarındaki İkilem Durumları: Aday Öğretmenler \\ Neler Yansitiyor? \\ Şeyda Selen ÇIMEN* \\ Şevki KÖMÜR**
}

\begin{abstract}
It has been suggested that if student teachers formally reflect on teaching dilemmas they confront, it may be possible for them to uncover new understandings of the teaching and learning process. The starting point of this study is to help student teachers be aware of their own conflicts in teaching English and talk about them explicitly, which is thought to lead them to make theory-informed evaluation of their ways of thinking and to stimulate the habit of reflective inquiry. Employing the qualitative approach, this paper outlines and interprets how student teachers in a practicum course in Turkey reflected on their teaching dilemmas just after they completed their teaching practice in their practice schools. The dilemmas student teachers reflected on were on three dimensions of a lesson: planning, managing, and conducting the lesson. The interpretations included conflicting thoughts, values, or expectations of student teachers throughout the teaching process as a whole and the issues that guided them in deciding on their courses of action.
\end{abstract}

Key words: Teaching dilemmas, student teachers, practicum, English language teaching.

\section{Öz}

Öğretme ve öğrenme süreçleri hakkında yeni anlayışların ortaya çıkacağı düşünüldüğü için, öğretmen adaylarının ders kapsamında öğretmenlik uygulaması sürecinde deneyimlediği ikilemler üzerine yansıtıcı düşünmeleri önerilmektedir. Bu çalışmanın çıkış noktası, aday öğretmenlere İngilizce öğretiminde yaşadıkları kendi ikilemlerinin farkına varmalarına ve bunları açıkça ortaya koymalarına yardım edebilmektir. Bu yol izlenerek, aday öğretmenlerin kendi düşünme sistemleri üzerine kuramsal bakış açılı değerlendirmeler yapmaya ve yansıtıcı sorgulamalar yürütmeye yönlendirileceği düşünülmüştür. Nitel yaklaşımı benimseyen bu çalışma, Türkiye'de öğretmenlik uygulaması dersini alan aday öğretmenlerin uygulama okullarında örnek derslerini tamamladıktan hemen sonra öğretim sürecinde yaşadıkları ikilemler üzerine ne düşündüklerini ortaya koymakta ve yorumlamaktadır. Aday öğretmenlerin yaşamış oldukları öğretme süreci ikilemleri, bir dersin üç boyutu olan planlama, yürütme ve yönetme boyutlarında yaşanan ikilemlerdir. Çalışmanın bulguları, bütüncül olarak, aday öğretmenlerin bir öğretme süreci içerisindeki çelişen düşüncelerini, değerlerini veya beklentilerini ve de bu ikilem durumlarında uygulamaya koydukları kararları nelerin yönlendirdiğini içermektedir.

Anahtar kelimeler: Öğretme süreci ikilemleri, aday öğretmenler, öğretmenlik uygulaması, İngiliz dili öğretimi.

\section{Introduction}

Teaching is a multi-dimensional job and teachers go through active mental processes before, during, and after each lesson. Before a lesson, they think actively to plan for what and how to teach; at the time of the lesson, they make on the spot decisions for various situations; and after the lesson, they evaluate the learning/teaching event. It is natural that teachers have instabilities during all those mental processes; and dilemmas can be regarded as such. Komorowska (2016) defined the term dilemma as:

The term dilemma is used to refer to situations in which a choice is to be made between conflicting expectations conflicting or competing values or two courses of action. (...) A dilemma may also reflect a hiatus between the teacher's convictions (beliefs) and the course of action he or she decided to undertake. (p. 82)

\footnotetext{
${ }^{*}$ Res. Assist. Dr., Muğla Sitkı Koçman University, Faculty of Education, Department of Foreign Languages Teaching, seydaselen@mu.edu.tr

** Prof. Dr., Muğla Sıtkı Koçman University, Faculty of Education, Department of Foreign Languages Teaching, coal@mu.edu.tr
}

Çimen, Ş. S. \& Kömür, Ş. (2019). Dilemma Situations in Teaching Practice: What Do Student Teachers Reflect?, Gaziantep University Journal of Social Sciences, 18 IDEA Special Issue, 168-177, Submission Date: 31-07-2019, Acceptance Date: 30-12-2019.

Araştırma Makalesi. 
In the literature, we encounter other terms as "difficulty" and "problem." Dilemma researchers have made a distinction between those concepts and the concept of dilemma since it can be confusing for the readers. Komorowska (2016) distinguishes between a dilemma and a difficulty in teaching contexts as "difficulty refers to an obstacle which hinders planned actions to be undertaken". Therefore, she says "not every difficulty can be treated as a dilemma, yet every dilemma is a form of difficulty" (p. 83). Similarly Scager, Akkerman, Pilot, and Wubbels (2017) separate a dilemma from a problem by considering the solution aspect and see a problem as something that can be solved; but "a dilemma cannot be solved without leaving some residue" (p. 319). Scager et al. (2017) take alternatives that create dilemmas at the center of dilemma situations and emphasize the fact that the act of choosing one will have both advantages and disadvantages. In parallel with Scager et al.'s (2017) view, Lampert (1985) adopts a "coping rather than solving" point of view about the dilemmas in teaching. That's to say; teachers had better learn to cope with dilemmas they face rather than trying to solve them since every option that is not chosen will be a remainder with its advantages and disadvantages.

Komorowska (2016, p. 83) classified dilemmas as contextual dilemmas, ethical dilemmas, and teaching dilemmas. Contextual dilemmas are described as dilemmas rooted in the organization of education and its legal foundations. Ethical dilemmas arise on an everyday basis in the life of schools. Teaching dilemmas, which is the focus of this study, are the ones that are connected with planning, managing, and conducting lessons as well as those connected with assessment and out-of-school activities. The scope of this study, however, is limited to teaching dilemmas experienced by student teachers of English which are connected to planning, managing, and conducting lessons. The starting point of the researchers was to help student teachers be aware of their own conflicts in teaching English and talk about them explicitly, which was thought to lead them to make theory-informed evaluation of their ways of thinking and to stimulate the habit of reflective inquiry. The aim of this paper is to uncover teaching dilemmas student teachers confront during practice teaching. To this end, this study addresses the following research questions:

1. What are the teaching dilemmas the student teachers confront in practice teaching?

2. What guided the student teachers to decide on the action they took?

\section{Research on Teacher Dilemmas}

Teaching is a situated activity. Every single class has its own contextual variations. Teaching is also "a dynamic phenomenon where interpersonal interactions occur explicitly and implicitly at multiple levels" (Watanabe, 2013, p. 91). The dynamic and situated nature of teaching is the main source of dilemmas that teachers encounter of various kinds. Teachers cannot escape dilemmas. However, they can equip themselves with strategies to manage them (Scager, 2017). Lampert (1985) images the teacher as a dilemma manager and suggests that "...the teacher herself is a resource in managing the problems of educational practice" ( $p$. 194). She presents her own case of dilemmas in her study and focuses not on the choice a teacher has to make in a dilemma situation but on the teacher's deliberation about the alternatives. Lampert (1985) further explains that choosing is not the only way to manage a dilemma because sometimes neither of the options can be the winner.

The scope of studies on teacher dilemmas varies. There are studies that present frameworks of dilemmas and the ones that aim to detect dilemmas faced in different aspects of teaching. On the other hand, there are also studies that focus on teachers' ways of coping with them. Windschitl (2002) scrutinized constructivism in practice and presented a framework that explicates conceptual, pedagogical, cultural, and political dilemmas faced by teachers. Yin (2015) examined Chinese teachers' dilemmas in the nation-wide curriculum 
reform and classified four types of dilemmas as cultural, structural, professional, and instrumental dilemmas (cited in Zhu, 2019). Scager et al. (2017) disclosed implicitly communicated dilemmas of teachers when challenging students in higher education and introduced a dilemma analysis instrument. They highlighted conflicts like "maximizing challenge versus maintaining students' psychological safety" that were caused in the process. Smagorinsky, Wilson \& Moore (2011) examined a beginning teacher's dilemmas in teaching grammar and writing and found that she was drawing on "inconsistent pedagogical traditions one centered on a teacher's authoritarian control of the curriculum and adherence to formal properties of texts and one centered on students' interests and their agency in learning" ( $p$. 262). Shapiro-Lishchinsky (2011) went further into ethical dilemmas and investigated them through critical incident technique, by which the researcher came up five main categories of ethical dilemmas such as "caring climate versus formal climate and confidentiality versus school rules" (p. 651). Among the studies examining teachers' strategies to cope with dilemmas, Helton and Ray (2006) focused on the strategies practicing teachers would employ to overcome ethical dilemmas. The study revealed four strategies as "preventing dilemmas from occurring; educating and/or threatening others; involving others in solutions; and combining strategies." A similar study that focuses on the strategies for eliminating ethical dilemmas by Ehrich, Kimber, Millwater \& Cranston (2011) provided with a model that includes strategies like sharing dilemmas with trusted others, having institutional structures in schools, and educating colleagues about specific issues.

Researchers have also examined dilemmas faced by pre-service teachers in different fields. In their study, Harvey, Cushion \& Sammon (2014) aimed to understand dilemmas faced by pre-service teachers' learning about and implementing a game-based approach in physical education lessons. They categorized the dilemmas they faced as conceptual, pedagogical, cultural, and political dilemmas. Donahue (1999) studied with four pre-service English teachers on the service-learning component of their teacher education program and highlighted the possibility of educating teachers morally for their profession by examining the ethical dilemmas they face throughout this component. Zhu (2019) examined six pre-service teachers' ethical dilemmas in shaping identity during teaching practicum (field is not identified) and listed tensions between the classroom authority or the care of teaching; being a community member or an outsider; being an office assistant or a real teacher; and conflicting pedagogies regarding teaching different tracks of students. Another study by Millwater, Ehrich \& Cranston (2004) investigated ethical dilemmas faced by pre-service teachers during their practicum and revealed dilemma situations regarding rights of individuals, rights of groups, and system requirements. Brocks, Case and Taylor (2013), with a twofold aim, focused on pre-service teachers' practices regarding literacy instruction and diversity among children together with a teacher educator's dilemmas in guiding them.

It is observed that ethical dilemmas faced both by practicing teachers and student teachers in different fields of education have been the focus of researchers in the existing literature. Therefore, it can be said that literature needs more studies focusing on teaching dilemmas faced by student teachers. This study attempts to provide insights into student teachers' dilemmas during teaching practice and uncover issues that guided them in reaching a decision.

\section{Method}

The study adopted a qualitative approach and the data were collected via "Teaching Dilemmas Record Sheet" (please see the appendix for the instrument), which was written by the researchers based on the literature on teacher dilemmas (Komorowska, 2016; Tillema, 1997; Tillema \& Kremer-Hayon, 2005 among others). Opinions of three experts as teacher educators were taken on "Teaching Dilammas Record Sheet." The instrument asked student 
teachers to (1) record the situations that caused dilemmas for them, (2) include contextual details about the lesson they faced dilemmas in, and (3) reflect on their actions/reactions against the dilemma situations. The sampling strategy used in the study was purposive sampling. The participants were a cohort of student teachers who were taking their practicum course in the last grade of a four-year language teacher education program. The characteristics of the participant group as being student teachers of English language and taking the practicum course were suitable for the purposes of the study. Participation to the study was on a voluntary basis and twenty-four student teachers participated by submitting their "Teaching Dilemmas Record Sheet" and eight of them by participating in the class discussions. The data collection period lasted throughout the spring semester.

\section{Procedure}

We aimed to examine teaching dilemmas student teachers experience during the teaching practice sessions carried out as a requirement of the practicum course. To this end, we elicited information from student teachers via a written instrument: "Teaching Dilemmas Record Sheet." First, we provided the student teachers with background information on what a teaching dilemma is based on the related literature (Komorowska, 2016; Tillema, 1997; Tillema \& Kremer-Hayon, 2005 among others). We asked the student teachers to complete “Teaching Dilemmas Record Sheet" just after they carried out their teaching practice. Each student-teacher submitted three record sheets in total. After submissions, class discussions were carried out with eight of the participants to have more insights on student teacher dilemmas. During the discussions, we wanted the student teachers to elaborate on the situations that caused dilemmas and the actions they took. Field notes were taken during the class discussions.

\section{Data Analysis}

Along with the traditions of qualitative research, the data collected from the student teachers were content-analyzed. The responses of student teachers were subjected to a systematic coding process. In the first cycle, in vivo coding was done and "the direct language of participants" (Saldana, 2011, p. 48) to explain the dilemma situations were picked. Then, the codes were critically examined in the second cycle and the patterns were constructed. Next, the patterns were allocated to pre-existing categories of planning, conducting, and managing as the aspects of a lesson, which were identified by Komorowska (2016).

\section{Results and Discussion}

Findings of the study are presented under the research questions presented one by one below.

\section{What are the teaching dilemmas the student teachers confront in practice teaching?}

STs' teaching dilemmas were investigated and they reported to confront thirteen different dilemmas in total during the teaching practice. When the dilemmas were classified according to the aspects of a lesson as planning, conducting, and managing, five dilemmas were allocated to the planning aspect, and four dilemmas were allocated to the conducting and managing aspects.

In the planning aspect, STs' dilemmas were mostly about including a technique or an activity in the lesson plan or not. The dilemmas they confronted were "to include explicit grammar instruction or not; to include games or not; to include more free production activities or mechanical drills; to include group/pair work or not; and to use the smart board or not." the model in the Figure 1 displays the dilemmas faced by student teachers in the planning aspect. 


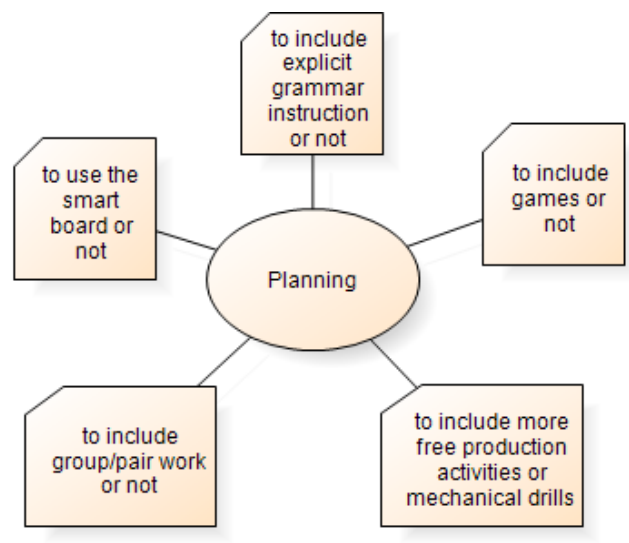

Figure 1: Teaching dilemmas student teachers confronted in the planning aspect

If we reflect on the dilemmas STs face in this aspect, it is observed that the dilemmas were caused by the existence of two alternatives for each situation, and further one alternative represents more traditional ways of teaching whereas the other alternative represents more contemporary ways. For instance, including explicit grammar instruction in the lesson plan, rather than relying on implicit grammar teaching, is regarded as a traditional way of teaching English. Similarly, including more free production activities in the lesson plan is regarded as a contemporary way of teaching English while including mechanical drills is regarded as oldfashioned. Extract 1 exemplifies the dilemma situations STs confronted in the planning aspect.

Extract 1

I was writing my lesson plan for my practice teaching session and I could not make up my mind for a long time. I had two ways: to include explicit grammar instruction in my lesson plan and explain the grammar rules, give metalinguistic information for example, or not. Then I decided to give place to explicit grammar instruction, at least briefly, because my mentor, who is the real teacher of this class, does so and both the students and the mentor herself are accustomed to it. (ST G)

In the conducting aspect, STs reported that they confronted four different dilemmas. They are "to use L1 or not; to correct accuracy mistakes or not; to tell meanings of words when asked or not; and to translate sentences in reading texts or not." Dilemmas faced in this aspect are illustrated by the model in Figure 2 below.

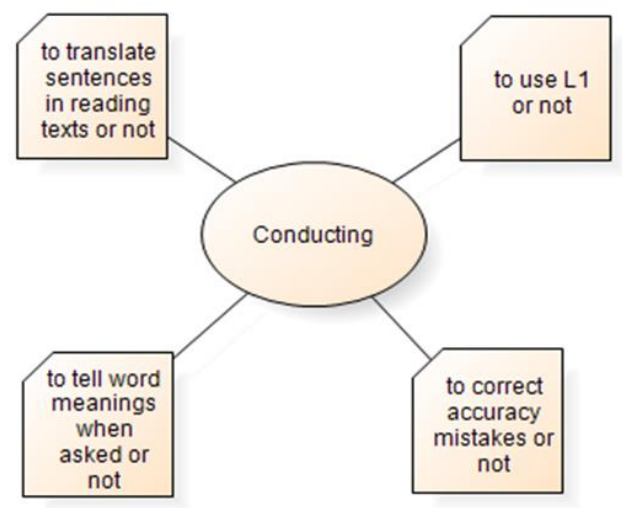

Figure 2: Teaching dilemmas student teachers confronted in the conducting aspect

STs expressed that they felt tension between the conflicting expectations of university supervisors and pupils' routine classroom life. To uncover the situation, we asked the STs to talk about the situation thoroughly in classroom discussions. They stated that mentor teachers 
at schools generally use L1 while explaining grammar points or giving instructions; they correct most of the accuracy mistakes even if the utterance conveys the message; and translate sentences in reading texts into Turkish in order to ensure understanding. Therefore, the pupils are accustomed to their teachers' ways of teaching and expect STs to do the same. However, university supervisors expect them to follow theories and principles of language teaching in their practice teaching sessions. Additionally, they also have their own beliefs and values about teaching. Consequently, STs have tensions between conflicting expectations of supervisors and pupils; have difficulty in choosing between different courses of action, and as a result confront dilemma situations. Extracts 2 and 3 exemplify the dilemma situations faced in the conducting aspect.

Extract 2

I was teaching the 7th graders and I gave instruction for an information gap activity in English. Some of the students asked me to explain once more in Turkish. For a second, I couldn't decide what to do. (...) My supervisor was observing my class and I thought that I shouldn't use L1 because she would most probably give me feedback on this point after the class. So I tried to explain once more but in English and by showing an example. Then they understood what to do for the activity. (ST B)

Extract 3

While I was practice teaching, a student asked me the meaning of the word 'describe' in Turkish and at that time, first I could not decide whether to tell the meaning in Turkish, define it in English, or tell him to look it up in the dictionary. But then I decided to tell him to look the word up in the dictionary because my mentor teacher always does so and advices us to do so. Additionally, I remembered my English teachers at high school always used the same technique. (ST K)

As for the managing aspect, STs reported four dilemma situations they confronted. They include "to ignore off-task behavior or not; to take mobile phones from students or not; to force the students who do not want to participate in the activities or not; and to deviate from the lesson plan or not." Dilemmas faced in this aspect are shown by the model in Figure 3 below.

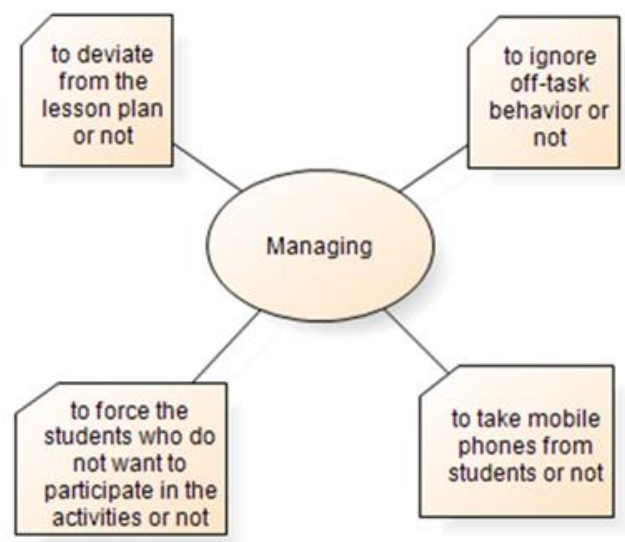

Figure 3: Teaching dilemmas student teachers confronted in the managing aspect

Classroom discussions revealed that some of the dilemmas they face in the managing aspect stem from the point that "do I, as a student-teacher, have the authority to do that?" STs expressed that they were not sure whether they had the right to take a student's mobile phone during the class time or to force a student who did not want to join a game. Extracts 4 and 5 exemplify the dilemmas STs had while managing the class.

Extract 4 
I was having a practice teaching session and at the very beginning of the lesson I noticed that a few students were playing with their mobile phones under the desks. I thought about whether to take their phones, only to warn them, or ignore. Then I thought that I didn't have the right to take their phones since I was not the formal teacher of this class. And I decided to make eye contact with them and later they understood what I meant and stopped that behavior. (ST KC)

Extract 5

I hesitated whether all the students would want to work together or not because there were students who came from different backgrounds in terms of race, culture, and level of learning. I planned a lesson based on songs to entertain them and encourage them. I picked the students from the list randomly in order to make them work together. (...) However, there were some students who did not want to be partners; especially they didn't want to work with the students who were from a different country. I couldn't decide what to do for a moment but I was determined to take action! Because I believe it is the teacher to change such attitudes. I talked to them kindly about not to discriminate anyone and they didn't reject my request. They continued the activity happily. (ST Ö)

On the other hand, some of the dilemmas they face in the managing aspect are thought to stem from lack of experience in classroom teaching. They expressed that they felt tension in choosing between acting upon the pupils' emotional states and deviating from the lesson plan or ignoring this and finishing up all the activities in their lesson plans. Similarly, off-task behavior of the pupils cause a dilemma situation for the STs in that they were not certain about ignoring the behavior or acting upon it; and if they choose the second alternative, how? Extract 6 shows a ST's dilemma situation while managing the lesson.

Extract 6

I was having a practice teaching class with $5^{\text {th }}$ graders. I wanted the students to enjoy my class but I noticed that the students were not attending. I think they were tired because it was Friday, the last day of the week, and they were also bored. I stopped a second and it was a true dilemma for me. I asked myself that should I stick to my lesson plan and carry on the tasks or should I stop with the lesson plan and do something to draw students' attention? That moment I told myself that a lesson plan should be flexible and decided to play a vocabulary game with students; because they always have fun with games. (ST M)

STs also reported that they felt more confident about the dilemma situations of this kind towards the end of the practicum as they gained experience in classroom teaching. When it comes to discussing the findings of the first research question, one can say that there is a lack of research on teaching dilemmas in planning, conducting, and managing aspects of a lesson. However, it is possible to relate the findings reported in this section to the findings of teacher cognition research. The following options of student teachers "to play games or not, to ignore off-task behavior or not, to force the students who do not want to participate in the activities or not, and to use L1 or not" in dilemma situations were presented as strategies generated by student teachers to deal with different types of challenges they encountered during practicum (Çimen, 2017).

\section{R.Q. 2: What guided the student teachers to decide on the action they took?}

Student teachers' responses and the classroom discussions indicated that the "mentor teachers, student teachers' own beliefs, university supervisors of the practicum course, and their previous teachers" guided them to decide on the actions they took in dilemma situations. It is obvious that mentor teachers' teaching habits, their previous teachers' classroom applications, university supervisors' expectations, and their own beliefs on teaching affected their decisions when they faced dilemma situations. For instance, in the extracts 1 and 3 above, student teachers clearly expressed that mentor teachers at schools guided their actions. In the extract 2 , it is obvious that the student-teacher was affected by the university supervisor's expectations; and in the extract 3 the student-teacher referred to the practices of 
his previous teachers. Student teachers in the extracts 4 and 5 fell back on their own beliefs about teaching to overcome a dilemma situation.

The findings of the study are parallel with most of the previous research on teacher cognition. Çimen (2017) found that mentor teacher recommendations and student teachers' own learning experiences with the previous teachers are among the factors that influence their teaching practices. Urmston (2003) is another study who reported the influence of student teachers' own learning experiences. Farrel (2008) specified the impact of teacher education program on student teachers' instructional practices. On the contrary, Penington and Urmston (1998) concluded that the coursework in the teacher preparation program did not affect student teachers much when compared to the influence of traditional teaching context.

\section{Conclusion}

As the present study suggests, faculty supervisors should take student teachers' dilemmas into consideration while supervising the practicum. Through scrutinizing student teachers' dilemmas, teacher educators can uncover their thoughts and delve into their understandings of teaching together with what lies behind their decisions in actual practice. The first step supervisors can take is helping student teachers be aware of the dilemmas they face during teaching; and the second is guiding them to sort out those situations. This constitutes a highly important part of teacher education since student teachers are at the initial point of their profession. The literature on dilemmas has reached the conclusion that focusing on dilemmas serves pre- and in-service teacher development and professionalism; provides insights about teacher beliefs; and supports reflection by encouraging thoughts on them to make informed choices and raise critical perspectives on practices (Komorowska, 2016; Kremer-Hayon \& Tilemma, 2002; Tilemma \& Kremer-Hayon, 2005; Scager, Akkerman, Pilot \& Wubbels, 2017).

The bulk of studies existing in the dilemma literature are on ethical dilemmas and a lack of research on teaching dilemmas is observed. This study attempts to contribute to the literature on teacher dilemmas first by outlining teaching dilemmas confronted by student teachers of English in planning, conducting, and managing aspects of a lesson; and then by uncovering the underlying influences that guided their decisions. However, further studies are required on teaching dilemmas to have a more complete understanding of dilemmas faced by teachers and student teachers. In addition to studying teaching dilemmas confronted in different aspects of a lesson, future research can also examine dilemmas by focusing on the teaching of specific aspects of language such as grammar, vocabulary, or language skills. Dilemmas confronted in assessment issues can also be focused on by researchers. Teacher journals, classroom observations, and stimulated-recall interviews which will be based on video recordings of the classes taught by teachers and student teachers can be suggested for future researchers as techniques for data collection in order to have a clearer picture of teaching dilemmas in language teaching.

\section{References}

Brock, C. H., Case, R. \& Taylor, S.S. (2913).Dilemmas in guiding pre-service teachers to explore literacy instruction and diversity. Teacher Education Quarterly, 81-100.

Cynthia H. Brock, R. C., \& Taylor, S.S. (2013). Dilemmas in guiding pre-service teachers to explore literacy instruction and diversity. Teacher Education Quarterly. $81-100$.

Çimen, Ş.S. (2017). A case study on pre-service English language teachers' cognitions and practices regarding most commonly experienced in-class challenges. Unpublished Doctoral Dissertation. Middle East Technical University, Ankara/Turkey. Retrieved 31 July 2019 from: https://tez.yok.gov.tr/UlusalTezMerkezi/tezSorguSonucYeni.jsp 
Donahue, D.M (1999). Service learning for preservice teachers: Ethical dilemmas for practice. Teaching and Teacher Education, 15, 685-695.

Ehrich, L. C., Kimber, M., Millwater, J., \& Cranston, N. (2011). Ethical dilemmas: A model to understand teacher practice. Teachers and Teaching: Theory and Practice, 17(2), pp. 173-185.

Farrel, T. S. C. (2008). Learning to teach language in the first year: a Singapore case study. In Novice language teachers: Insights and perspectives for the first year (Ed.) Farrel T. S. C. Equinox, 43-56.

Harvey, S.; Cushion, C. \& Sammon, P. (2014). Dilemmas faced by pre-service teachers when learning about and implementing a game-centered approach. European Physical Education Review, 21(2). 238-256

Helton, G. B., \& Ray, B. A. (2006). Strategies school practitioners report they would use to resist pressures to practice unethically. Journal of Applied School Psychology, 22(1), 43-65.

Komorowska, H. (2016). Dilemmas in language teaching and teacher education. Glotto Didaktica 63(1), 81-95.

Kremer-Hayon, L. \& Tilemma, H. (2002). Practicing what we preach. Teacher educators' dilemmas in promoting self-regulated learning: a cross case comparison. Teaching and Teacher Education, 18, 593-607.

Millwater, J., Ehrich, L.C., \& Cranston, N. (2004). Preservice teachers` dilemmas: Ethical or not? International Journal of PEPE Inc, 8(2), 48-58.

Pennington, M. C. \& Urmston, A. (1998). The teaching orientation of graduating students on a

BATESL course in Hong Kong: A comparison with first year students. Hong Kong Journal of Applied Linguistics, 3(2), 17-45.

Saldana, J. (2011). The coding manual for qualitative researchers. London: Sage Publications.

Scager, K., Akkerman, S. F., Pilot, A. \& Wubbels, T. (2017). Teacher dilemmas in challenging students in higher education. Teaching in Higher Education, 22(3), 318335. doi: 10.1080/13562517.2016.1248392

Shapiro-Lishchinsky, O. (2011). Teachers' critical incidents: Ethical dilemmas in teaching practice. Teaching and Teacher Education, 27, 648-656.

Smagorinsky, P., Wilson, A. A. \& Moore, C. (2011). Teaching grammar and writing: A beginning teacher's dilemma. English Education, 43(3). 262-292. Published by:

National Council of Teachers of English Stable URL: http://www.jstor.org/stable/23017093

Tilemma, H. \& Kremer-Hayon, L. (2005). Facing dilemmas: teacher educators' ways of constructing a pedagogy of teacher education. Teaching in Higher Education, 10, 203 217.

Urmston, A. (2003). Learning to teach English in Hong Kong: The opinions of teachers in training. Language and Education. 17(2), 112-137.

Watanabe, K. (2013). Teaching as a dynamic phenomenon with interpersonal interactions. Mind, Brain, and Education. 7(2), 91-100. 
Windschitl, M. (2002). Framing constructivism in practice as the negotiation of dilemmas: An analysis of the conceptual, pedagogical, cultural, and political challenges facing teachers. Review of Educational Research. 72(2), 131-175.

Zhu, G., Peng, Z., Deng, L., Li, G., \& Etchells, M. (2019). Student teachers' emotions, dilemmas and professional identity formation amid the teaching practicums. Paper presentation at the American Educational Research Association Annual Meeting. Toronto, Canada, April 5-9, 2019.

\section{Appendix}

\section{TEACHING DILEMMAS RECORD SHEET}

1. Describe the situation that caused dilemma with contextual details, please.

Aspect of the lesson (planning / conducting / managing):

Stage of the lesson:

Grade level:

Topic/Aim of the class:

Incident:

2. What were your competing/conflicting thoughts, values, or expectations?

3. What action did you take?

4. What guided you to decide on the present action?

What were other action(s) you considered to take at the time of the dilemma? 